\title{
Esâsî’nin Kaside-i Bürde Tercümesi
}

\section{Vesile ALBAYRAK SAK ${ }^{1}$}

\author{
APA: Albayrak Sak, V. (2019). Esâsî'nin Kaside-i Bürde Tercümesi. RumeliDE Dil ve Edebiyat \\ Araştırmaları Dergisi, (16), 343-273. DOI: 10.29000/rumelide.618956
}

\section{$\ddot{O} \mathbf{z}$}

Milattan önce V. yüzyıla kadar uzanan, Arap edebiyatının en parlak devrini oluşturan Cahiliye devri şiiri kaside, Arap şiirinin bilinen ilk ve en köklü nazım şeklidir. Kaside, Muallakat adı verilen ilk örneklerinden başlayarak edebiyatımıza intikal edinceye kadar birçok tecrübe geçirmiştir. Kaside-i Bürde ve Kaside-i Bür'eler ise Hz. Peygamber’i anlatan ve toplumda ma'kes bulan eserlerin başında gelmektedir. Ka`b b. Züheyr'in şiirine Hz. Peygamber'in hediye ettiği "hırkaya” istinaden Kaside-i Bürde, Busîrî’nin Hz. Peygamber’i rüyada görme sevinci ile derdinden kurtulması, "iyileşme"sine istinaden de Kaside-i Bür'e olarak anılsa da bu kasideler literatürde Kaside-i Bürde olarak tanınmaktadır. "Bedîiyyât” isminde yeni bir tür oluşturacak şekilde edebiyatı etkileyen Busîrînin bu eserinin çoğu Arapça olmak üzere edebiyatımızda birçok tercüme, şerh ve tahmisleri bulunmaktadır. Üzerinde çalıştığımız Esâsî’nin eseri de bu tercümelerden biridir. Hayatı, eserleri hakkında tezkire ve biyoğrafik kaynaklarda ismine rastlayamadığımız şair hakkında bilgiler yok denecek kadar azdır. "XVIII. Asır divan şairi, medrese mensubu" gibi birkaç kaynakta verilen bilgiler de tahminden öte geçmemektedir. Hakkında pek çok soru aydınlatılamasa da Esâsî isminin mahlası olması kuvvetle muhtemel olan şairin iyi yetiştirilmiş Arapça ve Farsçayı bu dillerden çeviri yapabilecek kadar iyi bilen bir âlim olduğunu söyleyebiliriz. Esâsî de bu manzum Kaside-i Bürde tercümesinde tıpkı diğer şairler gibi eserin aslındaki manayı muhafazaya çalışmış, Hz. Peygamber'e olan sevgisini bu eseriyle ortaya koyarak dinî-tasavvufi edebiyatımızın zenginleşmesinde rol oynamıştır. Çalışmamız şuara tezkirelerinde ismi geçmeyen Esâsî hakkında az da olsa bilgi vermeyi ve onun Hafız Hüseyin b.Ali’nin Busîrî̀nin Kaside-i Bürde'si ve ona yazılan tahmis ve tercümeleri topladı̆̆ı kitabındaki Kaside-i BürdeTercümesini ilim âlemine sunmayı amaçlamaktadır.

Anahtar kelimeler: Kaside, Kaside-i Bürde, Kaside-i Bür'e, Esâsî, tercüme.

\section{A Translation of Kaside-i Burde by Esâsî}

\begin{abstract}
Cahiliye Age's poem kaside is the first and the most radical verse type of Arabic Poetry,has rooted till

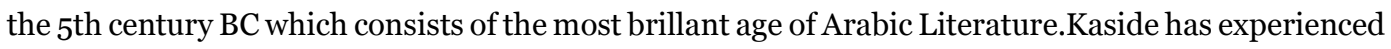
so many changes until it takes place into our literature by starting from its first samples called Muallakat. The Arabic literature has gotten into a new turning point due to the ayahs revealed from God to the Prophet Muhammad at the onset of the seventh century. During this period almost every phase of life has been re-organized and the qasida, written for a definite purpose, has been assigned to praise the prophet Mohammad. Since then, many literary works, within the tradition of writing in verse telling about the prophet Mohammad, reach the climax of lyricism. Kaside-i Bürde and Kasidei Bür'es are the leading works that tell about the Prophet and have the most interest in the community.
\end{abstract}

1 Dr. Öğr. Üyesi, Necmettin Erbakan Üniversitesi, Ereğli Eğitim Fakültesi,Türkçe ve Sosyal Bilgiler Eğitimi ABD, Türkçe Eğitimi BD (Konya, Türkiye), albayrak_vesile@hotmail.com, ORCID ID: oooo-00o1-5343-1099 [Makale kayit tarihi: 19.07.2019-kabul tarihi:19.09.2019; DOI: 10.29000/rumelide.618956] 


\begin{abstract}
Altough people call Ka'b b. Züheyr's poem, inspired by mantle of the Prophet and bestowed to him by the Prophet, and to Busîrî's poem, inspired by his recovery, getting out of his trobles with the joy of dreaming the Prophet, the Kaside-i Bürde; these qasidas are known as Kaside-i Bürde in literature. This work of Busîrî affecting the literature leading to a new kind to be created called Bedîiyyât has many translations, paraphrases and tahmises, most of which is in arabic. This study is one of Esâsî's these translations. There is almost no infomation about Esâsî in biographies. A couple of sources define him as the eighteenth century Ottoman poet, a madrassah member; but these are just guesses. Although we can not answer many questions about him, we can say that it is higly probable that Esâsî is the pseudonym of the poet who was a well educated scholar and he knew Arabic and Persian so well that he could even make translations in these languages. Esâsî, just like other poets, impressed by the Prophet that inspired our literature both as a human being and a Prophet as well, revealed his love of the Prophet through his translation of Kaside-i Bürde, and he helped our religious and sufi literature develop. Our study aims to give a little information about Esâsî, which is not mentioned in his tezkires, and to present his Kaside-i BürdeTranslation in his book, where he collects the interpretations and translations written by Hafiz Hüseyin b. Ali Buss Busîrî and the interpretations and translations written to him.
\end{abstract}

Keywords: Kaside, Kaside-i Bürde, Kaside-i Bür'e, Esâsî, translation.

\title{
Giriş
}

Şiir Arapların dışarıdan almayıp kendi geliştirdikleri bir bilimdi. Toplumsal yapısı özde kabileci olan Araplarda şair için kabile üyeliği her türlü değerin üstündeydi. Zira Arap geleneğinde şair sıradan bir insan ya da söz ustası olmayıp aynı zamanda varlığın ötesinden haber getiren insanüstü güçlerle gelişmiş, imtiyazlı bir seçkindi (Izutsu, 2013: s.21). Çünkü şair şiiri ve diliyle kabilesini o türlü savunurdu ki bunu kılıcı ve süngüsüyle bir süvari o ölçüde başaramazdı. Şiirin ve şairin Arap toplumundaki etkinliğini şuradan anlayabiliriz ki bir kere şair toplumun aşağı halli, namsız, nişansız bir ferdini övdü mü onun şanını yüceltir, öbür yandan şerefli bilinen ünlü kişileri de kötüledi mi onları aşağılayan şiirler söyledi mi etkisini hemen gösterirdi (Çelebi, 1997: s.165-166). Bir kabilede ünlü bir şair ortaya çlktı mı öbür kabilelerden heyetler gelir, o şairi tebrik ederlerdi. Sonra o kabile gösteriler düzenleyerek hayvanlar keser ve herkese yemekler yedirirdi. Söze ve şaire verilen önem sebebiyle Arap şiiri daha ilk asırlarda yetişen büyük şairler tarafından işlenmiş, birçok nevilere ve kollara bölünmüş, dinî, ticarî panayırlarda yapılan şiir yarışmaları sonunda yedi askı (seb`a-i muallaka) sahipleri olarak tanınan ünlü şairler ortaya çlkmıştır (Çağatay, 1957: s.137). İslam öncesine ait bu şiirler gerek beyit, vezin, kafiye gibi biçimsel yönleri ve gerekse muhteva hususuyla yani içerik yönüyle Arap şiirinin en gelişmiş formu olan kaside şeklindeydi.

Cahiliye devrinden Hicret’in ilk yıllarına kadar Arap şiirinde görülen başlıca iki nazım şeklinden ilki olan ve ani ilhamların etkisiyle irticalen söylenen "recez" sonraki yüzyllara pek az örnekle ulaşabilmiş, muallakaların nazım şekli olan kasidelerse ününe ün katmıştır. Cahiliye devrinin en büyük şairi olarak kabul edilen İmrü'l-Kays'ın muallakasından en genç şair Hâris'inkine kadar aşağı yukarı aynı ortak özelliklere sahip olan bu kasideler kahramanlık, içtenlik ve göçebe kültürünün bütün özelliklerine sahiptirler (Çavuşoğlu, 1986: s.107). Herkesçe uyulması zaruri ve belli bir kompozisyonu bulunan uzun bir manzume şekli olan bu kasideler üç esas kısımdan müteşekkil idiler. Başta yer alan nesib, şairin sevgilisinin çadırının bulunduğu yeri dolaşmasını, orayı terk edilmiş bulunca da üzüntülerini ifade ettiği kısımdır. Daha sonra övmek üzere yola çıktığı şahsın yanına varmak için yapılan seyahat ile bu esnada karşılaşılan güçlükler dile getirilir. Çölün ilgi çekici tasvirleri, dehşet veren sahneleri, binek 
hayvanlarının durumu bu kısımda tasvir edilir. Nihayet kasidenin gaye kısmı gelir ki bu da şiirin, adına söylendiği şahsın methini ihtiva eder.

Arap edebiyatı M.VII. asrın başlarında, tarihin en mühim dönüm noktasındaydı. Hz. Peygamber'e 610 yllında inmeye başlayan Kuran ayetleriyle, bu edebiyatta yeni bir döneme girilir (Furat, 1996: s.107).

Cahiliye devri artık duygu, düşünce ve değer hükümleriyle geride kalır.Hayatın hemen her safhası Kuran'a göre yeniden tanzim edildiğinden duygu, düşünce ve dilde değişiklikler tabiidir. Vicdana, akla ve duygulara hitap eden ayetler, Müslümanlarda, davranışları Allah'ın arzu ve emirlerine göre ayarlama düşüncesini yerleştirir. Ve bir amaç uğruna yazılan şiir olan kaside Hz. Peygamber’in övgüsüne tahsis edilir. Abdullah b. Revaha, Hassan b. Sabit, Ka'b b. Malik, Ka'b b. Züheyr gibi Peygamber şairlerinin öncülüğünde (Alan, 2014:s. 455) bir Peygamber edebiyatı başlar. Bu edebiyatta bu tahsis edilişteki sebepler şüphesiz Hz. Peygamber'in şefaatine mazhar olmak ve “ en sevgili "ye layı bir armağan sunmaktır. Bu sebeple İslam dünyasında dinî eserlerin manzum hâlde yazılması geleneği içinde çeşitli edebî tür ve şekillerde birçok eser ortaya konmuştur. Ezberleme ve akılda tutmanın ön planda olması gibi sade bir amaca dayanan bu metod dinî konularda birçok edebî eserin yazılmasına zemin hazırlamıştır (Eliaçık, 2009: s.15-17). Na't, Esmâ-i Nebî, Sîre (siyer), Mevlid, Hilye (şemâil-i şerîf), Ahlaku'n-Nebi, Mirâc-nâme-Mirâciyye, Mu'cizât-ı Nebî, Gazavât-ı Nebî, Hicretü’n-Nebî, Vefâtü’n-Nebî, Şefâat-nâme, Bi'set-nâme, Kırk Hadis, Yüz Hadis, Bin Hadis, Tıbb-ı Nebevî, Kaside-i Bürde ve Kaside-i Bür'e tercüme ve tahmisleri (Yeniterzi, 2010: s. 94) gibi Hz.Peygamber’i anlatan ürünlerle lirizmin doruğuna ulaşılır ve bu eserler toplumda ma'kes bulur.

Bu eserler arasında yer alan Kaside-i Bürde ve Kaside-i Bür'e'ler sadece İslam dünyasında değil Batı'da da ilgiyle karşllanan eserlerdendir. Kaside “ Bâned Suâdü Kasidesi” veya " Kaside-i Lâmiyye” olarak da isimlendirilmektedir. Babası meşhur Muallaka şairlerinden Züheyr b. Selma olan Ka'b’ın kardeşi Büceyr de bir şairdir. Mekke'nin fethinden sonra ve İslam'ın iyice yayılmaya başlaması yüzünden Ka'b'ın hayatı her gün biraz daha zorlaşıyor zaman onu Resulullah'ın hükmüne yaklaştırıyordu. Ka'b'ın imana kavuşacağı hususunda ümidini hiç kesmeyen kardeşi Büceyr, bizzat Resulullah'a onun Müslüman olması hâlinde affedilip affedilmeyeceğini sordu. Olumlu cevap alınca da bunu bir mektupla Ka'b'a bildirdi. Tanınmamak için tebdil-i kıyafet eden Ka'b, Medine'ye geldi. Mescidde Resulullah'ın huzuruna çıktı. Önce eman talebinde bulundu. Bu isteğinin kabulünden sonra da kimliğini açıkladı. Müslümanlardan hiddetlenenler oldu, fakat Resulullah onun bă̆ışlanıp güvence aldığını belirterek kendilerini teskin etti. Bunun üzerine Ka'b, sevgilisinin gidişinden bahseden ve "Bâned Suâd " sözleriyle başlayan kasidesini okumaya başladı:

"Suâd benden uzaklaştı, kalbim şimdi hüzünlü.

Onun arkasında perişan, fidyesi ödenmemiş, elleri zincirlerlerle bağlı hâlde...

Suâd yok artık, ayrılık sabahı kabilesi ile göç ederken,

Sürmeli gözlerinin mağrur ve müstağni bakışlarıyla inleyen bir ceylan gibiydi." (Kademoğlu, 200o: s.278).

Şair, geyiğe benzettiği sevgilisi Suad'ı anlatarak kasidesini okumaya devam etti; devesinden bahsettikten sonra sözü Resulullah’tan korkusuna ve af talebine getirdi.

Resulullah kendisinden ışı alınan bir nurdur. O, Allah’ın itina ile yapılmış ve kınından çıarılmış kilıcidır. 
Mısraları okununca, Peygamberimiz çok duygulanmış ve sırtından çıkardı̆̆ı bürdesini (hırkasını) Ka‘b’ın omuzlarına koymuştur. Bu hadise sebebiyle söz konusu kaside "Kaside-i Bürde" adıyla meşhur olmuştur. Bu emsalsiz hediyeyi ömrü boyunca titizlikle koruyan Ka`b b. Züheyr, Emevi devrinde Muaviye'nin teklif ettiği on bin dirhem karşılı̆̆ında dahi hırkayı satmamıştır (Kademoğlu, 2000: s. 279).

Tamamı 57 veya 59 beyit olarak değişen kasidenin 38 beyitlik nesib bölümünden sonraki beyitlerde Hz. Peygamber'e övgü yer alır.

İşte Ka'b b. Züheyr ve Hassan b. Sâbit’ten itibaren İslam dünyasında yetişen şairler, deha ve sanatlarının en olgun ürünlerini Hz. Peygamber için yazmış oldukları na't ve kasidelerde ortaya koymuşlardır. Bunlardan bazısının eseri sanat değerinden çok kazandığı şöhret bakımından diğerlerinden daha şanslı sayılmaktadır. İşte bu kervanın önde gelenlerinden biri 13. yüzyılda Mısır'da yaşamış olan Muhammed el-Busîrî̀dir.

Busîrînnin künyesi Ebû Abdullah, lakabı Şerefü’d-dîn'dir. H.6o9 (M.1212 ) senesinde Mısır'da Busîr şehrinde doğduğu rivayet edilen şairin, Ebü’l-Abbâs-ı Mürsî’nin talebesi olup iyi bir eğitim gördüğü, Hadis ve Siyer ilimlerinde büyük bir âlim olduğu, İslam dinini çok iyi bildiği gibi Yahudi ve Hıristiyanlığı da çok iyi bildiği, bu dinlerdeki tutarsızlık ve tahrifatı beyan ettiği ifade edilmektedir. H.695 (M. 1295)'te Mısır'da İskenderiye şehrinde vefat eden Busîrînnin Kaside-i Bürde başta olmak üzere:
a. El-Kasidetü'l-Hemziyye fi Medhi'n Nebeviyye
b. Zuhru'l-Meâd fi Vezni Bâned
c. El-Mührec ve'l-Merdûd ale'n-Nasârâ ve'l-Yahûd
d. El-Kasidetü'l-Mudâriyye fi's-Salâti alâ Hayri'l-Beriyye
e. Takdisü'l-Harem min Tednisi'd-Darem
f. El-Kasidetü'l-Hamriyye
g. Et-Tevessül bi'l-Kur'ân
h. Divanü’l-Busîrî,

gibi eserleri de mevcuttur (Hilmi, 2013: s.9-12).

Üzerinde çalıştığımız Esâsî'nin Kaside-i Bürde'si de dâhil olmak üzere diğer birtakım Kaside-i Bürde'ler ise Mısırlı sûfî ve şair Muhammed b. Said el-Busîrî'nin Hz. Peygamber için yazdığı eserinin tercümesidir. Orijinal ismi "El-Kevâkibü'd -dürriyye Fi Medhi Hayri'l-Beriyye" olan eser "yaratıkların en hayırlısını öven inci-ylldılar" anlamına gelmektedir. Şair Busîrî, Peygamber sevgisi ve onu rüyada görme sevinci ile dertlerinden kurtulduğu için ona, iyileşme anlamında "Bür'e" denmiştir. Hırkalı, anlamında "Bürdiyye”adı da verilmiştir. “ Bürüyen”, "Kurtuluş Kasidesi”, "Şifa Kasidesi” gibi isimlendirmelerde de bulunulmuştur (Sezer, 2000: s. 65).

Aruzun basit bahriyle yazılan, yapı ve üslûp bakımından son derece sağlam ve lirik olan eser, Busîrînin Hz. Peygamber hakkında yazdığı ve tamamına yakını manzum olan kasidelerinden biridir (Kaya, 1998: s. 38). Gerek mevzûu gerekse edebi kıymeti itibariyle Kuran dili ile yazılmış dünya şaheserlerinin ön saflarında yer alan eser, Kasidetü'l-Bür'e diye anılsa da literatürde Kasidetü'l-Bürde olarak tanınmaktadır (Armutçuoğlu, 2009: s. 5-18). En eski kaynaklarda 160 beyit, daha sonraki nüsha ve şerhlerde 165 beyte kadar çıan eserin 12 beyti nesib olup 16 beytinde nefsinden ve nefsinin isteklerinden; 30 beytinde Hz. Peygamber'e övgüden; 19 beytinde Hz. Peygamber'in doğumundan; 10 
beytinde kendisine dua edenlerden; 17 beytinde Kuran-1 Kerim'den; 13 beytinde miracdan; 22 beytinde cihaddan; 14 beytinde istiğfardan ve 9 beytinde Allah'a yakarıştan (münacaat) bahsedilir.

Çoğu Arapça olmak üzere edebiyatımızda birçok tercüme, şerh ve tahmisleri bulunan kaside Peygamber aşığı olan şairlerin bu vadide bereketli ürünler vererek bir İslamî edebiyat oluşturmalarında önemli rol oynamıştır. Süleyman Nahîfi (1842-1879), Mustafa Maksud Resâ, Kureyşîzâde Mehmed Fevzi (1867), Muhammed Fevzî (1856)( Kuzubaş, 2007: s. 156) tahmislerinin yanı sıra Raif Mehmed (Mollacıkzâde), Abbas Fevzi Dağıstanî (1893), Kemâlî Kemâleddin Mehmed Efendi (Taşköprîzâde) (Kahraman, 1991: s. 173) gibi şairlerin Türkçe; Nahîfî ve Şeyhülislâm Yahyâ'nın Arapça, Farsça hatta Said Paşa (Albayrak Sak, 2013: s.523) gibi bir kısım şairlerin de Türkçe, Arapça, Farsça üç dilde tahmisleri de kaleme aldıkları bilinmektedir.

Eserin Türkçe tercümelerinden bazıları ise Ahmed Mekkî, Abdurrahim Karahisârî (Kahraman, 1997: s. 57-107), Şemseddin Sivâsî (Albayrak Sak, 2014: s. 91-110), Marmara Müftüsü Hulûlî, Seyyid Ahmed Leâlî ve Kemal Paşazâde'ye (Saraç, 1995: s. 93-110) aittir. İslam âleminde büyük şöhret kazanmış bu kaside defalarca neşredilmiş, sayısız tercüme, şerh (şerhlerden biri Seyyid Hasan Rızâyî El-Aksarâyîye ait olup üzerinde çalışılmıştır.) (Cankurt, 2015:s.11), tahmis, teştir, tezyilleri yapılmıştır (Şahin, 1997: s. 56). 110'dan fazla şerh, 58 tahmis, 8 tesbi, 18 taştir, 2 tezyil ve sayısız nazirelere sahip eser Batı'da da ilgiyle karşılanıp Latinceye çevrilen eserler olma özelliğini göstermektedirler (Kaya, 2011: s. 14).

Ayrıca Hafız Seyyid Hüseyin b. Ali, Busîrînin metni de dâhil yapılan tahmis ve tercümeleri bir nüshada toplamış, her birini ayrı renk mürekkeple düzenlemiştir. Şerif Efendi (tahmis, siyah), asıl metin (Arapça, altın yaldız), Cami (Farsça, tercüme, kırmızı), Kemalpaşazâde (tercüme, siyah), Şemseddin Sivâsî (tercüme, siyah), Karahisârî Abdurrahim (tercüme, kırmızı), Esâsî (tercüme, lacivert), Ahmed Laelî Efendi (ortada yeşil mürekkeple şerhi ve sonda siyah mürekkeple tercümesi) bulunmaktadır.

Hz.Peygamber'e olan sevgisiyle İlahiyye, Muhammediyye, Mudâriyye ve Hemziyye gibi birçok kaside yazan şairin en kıymetli kasidesi şüphesiz Kaside-i Bürde'sidir. Söz konusu eser İslam dünyasında büyük rağbet görmüş, İslami edebiyatı asırlar boyu etkilemiştir.

Busîrînnin söz konusu kasidesinin de etkisiyle Peygamberimizin methine dair her beyitinde bir söz sanatının bulunduğu kaside yazma geleneği oluşmuştur. Bu edebî türe “ Bedîiyyât” adı verilmiştir. Her ne kadar Cahiliye Devri’nden beri Arap edebiyatında örneklerinin görüldüğü hatta Hassân b. Sâbit ve Ka'b b. Züheyr gibi şairlerin Hz. Peygamber hayatta iken bu tür şiirler yazdığ 1 ifade edilse de (Eğri, 2013: s. 151-152) H. 7. Asırda Ali b. Osman el-Erbilînnin (öl.1271-72) yazdığı ve her beytini bir bedîî sanata ayırdığı methiye kasideyle bu usulü ilk olarak onun ortaya koyduğu kabul edilir. Yaklaşık bir asır sonra Safiyyüddin el-Hıllî’nin (öl.1349) Peygamberimizin methine dair yazdığı ve her beyitinde bir bedîi sanatın bulunduğu 45 beyitlik kasidesi (Bahr-ı basit ile ve mim kafiyesi ile yazılmıştır) üslûp bakımından genellikle takip edilen örnek olup el-Kâfiyetü'l-Bedîiyye fi'l-Medâihi'n-Nebeviyye adını taşımaktadır. Günümüze ulaşan veya haberdar olunan bu türe ait kaside sayısı 10o'den fazladır. Bu türde örnek verenler yazdıkları şiirlerin ayrıca şerhini de yazmışlardır. Osmanlı ilim-kültür dünyasınca tanınan isimlerden Süyutî (ö.1505), Abdülgani en-Nablusî de (ö.1730) bu edebî türde eser veren şahsiyetlerdendir (Saraç, 2012: s. 285-286). Edebiyatta kaside-i masnû́a ile karıştırılsa da (Güleç, 2013: s. 69) Bedîiyyât adı verilen ve kaside-i masnû́adan farklı olan bu türün özellikleri şunlardır: Öncelikle bu kasidelerde Peygamberimizin methi konu edilmiştir. Vezni aruzun bahr-i basit’idir. Kafiyedeki revi harfi mim'dir. ( $\mathrm{Bu}$, üslûp bakımından İmam Busîrînin Kaside-i Bürde'sinin tesirinden ileri gelmektedir.) İşlenen sanat beytin ilk anlam düzleminde görülmez, birtakım rumuzlarla ya buna işaret 
edilir veya hiç edilmeden bunun bulunması şarihe ve okuyucuya bırakılır. Bundan dolayı da bu kasideler her zaman şerhe ihtiyaç duyar. Bu kasideleri yazanlar arasında ilmî yönleri edebiyatçı yönlerine ağır basan şahsiyetlerin çokluğu dikkat çekicidir (Saraç, 2012: s. 286).

Ahlakı Kuran olan bu elçiyi anlatmak, O'nun şefaatine mazhar olmak, O'na layık bir armağan sunmak vesileleri ile Hz. Peygamber'in sağlığında kendisine sunulan şiirden hoşnut kalması bu yolda yürüyenleri teşvik etmiş, şairler $\mathrm{O}$ en sevgili'yi layıkı vechiyle anlatabilme gayretine girmişlerdir.

İşte bu gayrete talip şairlerimizden birisi de Esâsî'dir. Hayatı, eserleri ve daha başka hiçbir soruyu cevaplayamadığımız; tezkire, biyoğrafik kaynaklarda ismine rastlayamadığımız şair hakkında bilgiler yok denecek kadar azdır. Elde edebildiğimiz bilgilerden ilki Türk Dili ve Edebiyatı Ansiklopedisi'nin verdiği şu kısa bilgidir: "Divan şairi (XVIII.a). Hayatı hakkında malumat bulunmayan Esâsî ile ilgili olarak sadece Sadeddin Nüzhet Ergun'un yazmalardan elde ettiği kısa bilgi mevcuttur."(1979: s. 90) Türk Şairleri’nde ise "Kaside-i Bürde mütercimi, XVIII. asır şairlerinden olduğunu tahmin ettiğim medrese mensubu şahsiyetlerdendir. Hayatı hakkında hiçbir menbada malumata rastlamadım. Millet Kütüphanesi'nde bir mecmuada 161 beyitten ibaret manzum bir "Kaside-i Bürde" tercümesi kayıtlıdır. Aslındaki manayı muhafazaya çalışarak yapılan bu tercümeden bazı beyitleri örnek olarak dercetmekle iktifa ediyorum.”(Ergun, 1936: s. 1341) gibi kısa bir bilgi geçmekte ve sekiz beyit örnek olarak verilmektedir. Bu kaynakların verdiği bilgiler de kesinlik arz etmemektedir. Esâsî veya Şeyh Esâsî isminin şairin mahlası olması kuvvetle muhtemeldir. Mevcut bilgi ve belgelerin yetersizliği sebebiyle Esâsî̀ye ait pek çok soru aydınlatılamasa da yaptığı tercümeden yola çıkarak iyi yetiştirilmiş, Arapça ve Farsçayı bu dillerden çeviri yapabilecek kadar iyi bilen bir âlim olduğunu söyleyebiliriz. Şair ve hakkında bilinmeyenlere Esâsînin söz konusu eseri dışında başka eserinin olup olmadığı da dâhildir.

Esâsî’nin manzum Kaside-i Bürde Tercümesi Hafiz Seyyid Hüseyin b. Ali’nin Busîrînin metni de dâhil yapılan tahmis ve tercümeleri bir nüshada topladığı Süleymaniye Kütüphanesi, Aşir Efendi, Nu:301'de kayıtlı 7b-87b arasında yer almaktadır. Yer yer mürekkep dağılmaları nedeniyle okunamaz durumda olan bu nüshadaki bazı beyitler yine Esâsîye ait Millet Kütüphanesi Nu: 886'da kayıtlı daha iyi bir nüsha ile desteklenmiştir. Kaside-i Bürde tercümelerinin tipik bir örneği olan eser diğer tercüme eserlerde karşılaştığımız gibi ana eserin kelime hazinesinden yararlanmıştır. Kaside-i Bürde tercümeleri Kurân-ı Kerîm tercümeleri gibi değerlendirilmiş; seḳam, münfețım, ketem, șavm ve daha birçok kelime "anlamı bozmamak" adına ana metinden aynen alınmış ve aslına uygun bir tercüme ortaya konmaya çalışılmıştır. Edebiyatta görülen eserin konusu aktarılarak yapılan çeviri anlayışı Kaside-i Bürde tercümelerinde pek uygulanmamıştır. Esâsî de eserini bu minvalde ortaya koymuştur. Bu nedenle dil yer yer ağırlaşmıştır.

$$
\begin{aligned}
& \text { Halḳı ile hulḳı kāmil bī-bedel șun'-ı 'acīb } \\
& \text { Müştemil ḥüsni ḳamu eylükler ile müttesim } \quad \text { b.54 }
\end{aligned}
$$

Bōstān-ı dehrde mādem ese bād-ı șabā

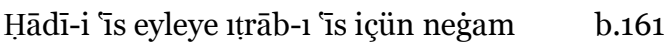

Şair, Fâilâtün/ Fâilâtün/ Fâilâtün /Fâilün vezninde kaleme aldığı, az da olsa vezin hatalarının bulunduğu 161 beyitlik manzum eserinde kafiye kullanımında da ana esere bağlı kalmıştır. 


\section{Sonuç}

Bu çalışmamızda Arap edebiyatında şiir ve şairin öneminden, daha Cahiliye döneminde gelişimini tamamlamış kasideden, Kaside-i Bürdelerden, Busîrî ve onun Kaside-i Bürde'sinin edebiyata, edebiyatımıza etkilerinden ve ona yazılan tahmis ve tercümelerden kısaca bahsedilmiş, Esâsînin Hafız Seyyid Hüseyin b. Ali’nin Busîrînnin metni de dâhil yapılan tahmis ve tercümeleri bir nüshada topladığı Süleymaniye Kütüphanesi, Aşir Efendi, Nu:301'de kayıtlı 7b-87b arasında yer alan manzum Kaside-i Bürde Tercümesi ele alınmıştır. Yer yer mürekkep dağılmaları nedeniyle okunamaz durumda olan bu nüshadaki bazı beyitler yine Esâsîye ait Millet Kütüphanesi Nu: 886'da kayıtlı başka bir nüsha ile desteklenmiş, bu nüshadaki farklıllklar gösterilmiş, iki metin karşılaştırılarak sağlam bir metne ulaşılmaya çalışılmıştır. Şairin bu ana kadar ortaya konmayan bu eserinin Türkçe mısraları okunup transkripsiyonu yapılmış, eser ilim âlemine sunulmuştur.

Fâilâtün/ Fâilâtün/ Fâilâtün /Fâilün vezninde kaleme alınan, az da olsa vezin hatalarının bulunduğu eser, Busîrînin söz konusu eserine bağlı kalınarak yapılmış, manzum tercümelerden biridir. Çalışma adeta bir ibadet telakki edilen ve pek çok şairin bu bakış açısıyla kaleme aldığı eserlerdendir. Hayatı, eserleri hakkında doyurucu bilgilere ulaşamadığımız Esâsînin Kaside-i Bürde tercümesini ilim dünyasına sunarak, şair ve eseri hakkında az da olsa bir kapı araladığımızı umuyoruz. Bizce Esâsî bu manzum Kaside-i Bürde tercümesinde tıpkı diğer şairler gibi eserin aslındaki manayı muhafazaya çalışmış, Hz. Peygamber'e olan sevgisini bu eseriyle ortaya koyarak dinî-tasavvufi edebiyatımızın zenginleşmesinde rol oynamıştır.

\section{Esâsî’nin Kaside-i Bürde Tercümesi²}

7b 1 Yāduña düşdi mi göñlüm hem-civār-ı zī-selem

Ki_aḳıdursın gözlerüñden ḳanlu yaşı dem-be-dem

$8 \mathrm{a}$

2 Kāẓımeden yā meger yil esdi geldi būy-ı dōst

Yā İżamdan şimşek oynadı giceyken pür-ẓulem

8b 3 Gözlerüñe noldı ag̉lama diseñ giryān olur

Gönlüñe noldı gider hüüni diseñ ister o gam

4 Şöyle mi șanur ki āş̧ı̣ sevgisi șaḳlu ola

Şol ikinüñ ortasında kim biri od biri nem

$9 b$

5 Ger hevā olmasa dökmezdüñ țalel üzre yaşuñ

Gözden uyḩuñ ḳaçmaz idi yād idüp bān ü 'alem

$10 \mathrm{a}$

6 Niçesi inkār idersin 'aşḳı varken şāhidin

‘Ādil ü nāfiz birisi dem ’ birisi seḳam

"M” Millet Kütüphanesi; "VB”: Vezin Bozuk.

Eserin M’ nüshasında yuvarlak eklerin daraldığı gözlenmiştir. 
10b $\quad 7 \quad$ 'Aşḳı sāābit ḳıldı yüzde haț̣u eşk ü lāgarı

Șan iki yanag̉uñ eşk üzre bahār ile ‘anem

11a 8 Göñlüme geldi hayāl-i yār gözden gitdi ḩ̌āa

‘Āşı̣̣a ādet-durur her lezzzet içinde elem

11b 9 Ey beni 'aşḳ içre ḳınayan kişi måzūur țut

Luṭ̂ ḳıl inșāfa gel özrüm ḳabūl it ḳıl kerem

12a 10 Saña zāahir oldı hāāim țuydı a dā sırrımı

Nāme-i derdimde haț̣āṭ̂-ı ezel yazmadı raḳam

12b 11 Sen baña ḳılduñ nașịhat țutmadum ben gūşımı

Ehl-i 'aşḳa 'ādet olmışdur melāmet de șamem

13a 12 Töhmet itdüm pīrlik pendi beni levm idicek

Dūrdur gāayetde pend-i şeybden gerçi tühem

13b 13 Nefs-i emmārem naṣihhat ḳılmadı hergiz ḳabūl

Bilmedügünden nicesi ḳorḳudur şeyb ü herem

14a 14 Ķonuk ag̉ırlamak içün bir iyi iş itmedi

Kondı mihmān başıma olmadı benden muhteșem

14b 15 Bilmeseydüm ḳonugga izzet ḳlamayacağum

Ketm iderdüm șaḳalumuñ aġına urup ketem

16 Kim-durur yola getüre iş bu azgun nefsimi

Nitekim hayl azgunını getürür yola lücüm

15b 17 İsteme iṣyān ile ger ola nefsüñ şehveti

Şehveti ḳılur ḳavī olsa yimekle pür-şikem

16a 18 Ṭıl gibidür bu nefis mādām ki süd virseñ emer

Līk südden kesseñ anı olur ol dem münfețım

$16 b$

19 Ḳıl ḥazer nefsüñ hevāsından ki ḥākim olmaya

Kande kim ḥākim hevā-yı nefs ola dīn ola kem 
20 Nefsüñe rıfḳ u ríāyet ḳıl ki tā ḳıla ’amel

Alıcak haz ol ibādetden anı da çekme gam

$17 \mathrm{~b}$

$18 \mathrm{a}$

$18 \mathrm{~b}$

$19 \mathrm{a}$

$19 b$

$20 \mathrm{a}$

$20 b$

$21 \mathrm{a}$

$21 \mathrm{~b}$

$22 \mathrm{a}$

$22 b$

$23 a$

21 Kişiye şerbet virür emmāre līkin zehrdür

İçer anı bilemez vardur disem içinde sem

22 Toḳluḳ açlık fitnesinden havf eyle dā'imā

Ġāyet açlı̣̆dan gehī olur ki hayr olur tuham

23 İtdügüñ ișyān içün țolan gözüñ yaşını dök

Rabbinüñ dergāhına eyle tażarru’ ḳıl nedem

24 Ol muhāâlif nefs-ile şeyțāna dahı 'āṣī ol

Gerçi saña pend dahıı itse_anları bil müttehem

25 Anlara ḩașm ü ḥakem yüzünden olmaġıl muṭ̂̄

Çün bilürsün niçe olur hịle-i ḩașm ü ḥakem

26 Ḥaḳka istiğfār iderem şol 'amelsüz ḳavlden

İsterem zֵürriyyet andan kim ola șāḥib-'aḳam

27 Huayr ile emr eyledüm saña velī ben itmedüm

Baḳma söyleyene baḳ sözine dir ehl-i hịkem

28 'Āhiret zādı içün bir nāfile işlemedüm

Ḳılmadum gayr-ı șalāt-ı farż ü gaayr-ı farż-ı șavm

29 Zālim oldum sünnetine enbiyā sulțānınuñ

Șubhādek ḳāimlig̈inden ayaġı oldı verem

30 Açlı̀̇ından țaş bag̉lardı mübārek ḳarnına

Anuñ altında be-ḡāyet mertebe nāzük edem

31 Geldi altundan yüce țag̉lar ḳabūl it didiler

Eyledi irrāż iẓhār itdi gāyetde şemem

32 Terk-i dünyā ḳıldı zühdinden żarūret var iken

Her ne deñlü kim żarūret olsa gāāibdür 'așam 
Olmasa çıḳmaz idi ketm-i ademden berr ü yem

24a 34 Kā’inātuñ eşrefi faḩr-ı Muhammed ekmeli

Seyyid-i mülk-i `Arab sulțān-ı iḳlīm-i 'Acem

24b 35 Emr idici nehy idicidür nebīmüz bir eḥad

Yoḳ kim andan gerçek ola lā dise yāhūū ne’am

25a 36 Ol Habību'llāhdan umar șefā'at ümmeti

Dilese eāṣileri rabbinden ol șāhib-kerem

25b 37 Dávet itdi ḳullarını Haḳka țutan emrini

Fi'l-ḥaḳiḳa dutmuş olur ḥabl-i gayr-ı münfașım

26a 38 Enbiyādan fầiḳ oldı ḩalḳda hem hulḳda

Anda ḩatm oldı nübüvvet hem dahı ilm ü kerem

26b 39 Enbiyā cümle Resūlullahdan eylerler ricā

Her ne olur bahırıdan ${ }^{4}$ garḳ ola yaraşır diyem

40 Enbiyā yirlü yirince ḳıldı öñinde vuḳūf

‘̇̇lmden bir noḳta ola ḩațtı yā ṣāḥib-ḥikem

27b 41 Oldur ol kim șūret-i mánāsını ḳılup tamām

Kendüye maḥbūb idindi șāḥib-i levḥ ü ḳalem

42 Gelmedi gelmez meḥāsinde aña beñzer beşer

Cevher-i hüüsn-i Muhammed oldı gaayr-ı münḳasım

28b 43 Hażret-i 'Īsāya didügin nașārānuñ dime

Her ne dirseñ Aḥmediñ medḥinde di iy mā-ḥakem

$29 \mathrm{a}$

44 Nisbet eyle zāàt-ı pākine ne kim olsa şeref

Nisbet eyle ḳadrine her ne ḳadar olsa izam

29b 45 Fażl ü cāh ü rütbe vü ḳadrine hạad yoḳdur anuñ

Niçe rūşen eyleye bile anı bu nuṭk-ı fem 
46 Olsa idi mu’cizātı ḳadrine göre 'aẓim

Cān bulurdı ${ }^{5}$ nāmı yād olsa hāa olmış rimem

3ob 47 'Aḳl ‘āciz oldığılen bize teklīf itmedi

Rāżı olduḳ emrine biz dahıı bī-reyb ü nehim

48 Fehm-i månā-yı Habību'llāhda 'ācizdür 'uḳūl

Bir ehad yoḳdur ırak yaḳın k’ide anı fehim

31b 49 Gidgide_ıraḳdan güneş gibi6 kiçirek7 görinür

Dīdenüñ nūrın ${ }^{8}$ ḳamaşdurur aña bulsa emem

50 Halḳ-ı dünyā niçe idrāk eylesün māhiyyetin

Uyhudadurlar9 bile her kişi uyandugi dem

32b 51 '̇lmimüz irişdügi bu kim beşerdür ol Resūl

Kāinātuñ ${ }^{10}$ yigregidür ol nebiyy-i muhteşem

52 Her ne deñlü kim getürdi mu'cize Rüsl-i kirām

Ol Muhammed nūrıdır hep cümlesine münḳașem

53 Ol risālet āsumānında güneş gayrı nücūm

Rū-şināsī encümüñ ẓāhir olur vaḳt-i ẓulem

54 Hualḳı ile ḩulḳı kāmil bī-bedel șun'-ı 'acīb

Müştemil ḥüsni ḳamu eylükler ile müttesim

55 Șanki nāzük gül-durur ${ }^{11}$ yāhūūd şeref burcında māh

Baḥrveş dā'im keremde dehrveş 'ālì-himem

Bir yire gelmiş dururlar 'asker ü hayl ü hasşem

\author{
M.'de "bulurdu" \\ M.'de "Göge" \\ M.'de "küçürek" \\ M.'de "nūrmndan" vB. \\ M.'de "Uykudadırlar" \\ M.'de "Kāyinātuñ " \\ M.'de "güldür" VB.
}


$35 \mathrm{~b}$

57 Lü’lü-i meknūn-durur gūyā șadef içre sözi

‘Āleme ḳıldı nisāâr ol dürden ol șāḥib-kerem

$36 \mathrm{a}$

58 Cism-i pāki țurdugi yirdür zemīnüñ eşrefi

Devlet anuñ kim öpe ol āsitānı ḳıla şem

36b 59 Ṭog்dıġı dem zāhir oldı unșurı gökçekligi

Pākligiylen oldı aña mübtedā vü muhtetem

$37 \mathrm{a}$

60 Bildiler Fürs ehli şimden girü irer anlara

Bī-nihāyet derd ü miḥnet bī-'aded renc ü niḳam

37b $61 \quad$ Ṭāḳ-ı Kisrā oldı şaḳ țog̉dug̉ı gice ol Resūl

‘Askerinüñ nite kim aḥvāli ġayr-ı mülte’im

38a 62 Söndi ${ }^{12}$ tersālar odı ḳılup teessüf ḥāline

Șuyunı ḳurıtdı ırmag̉uñ sedem yånī nedem

38b 63 Sāve gam-gīn oldı yire batduġı içün șuyı

Șu yerine oldı ehlinüñ içi pür-gayz ü gam

$39 \mathrm{a}$

64 Șanasın kim āteşi șu gibi oldı serd ü ter

Ḥüzn-ile gūyā ki șu od gibi oldı pür-żaram

39b 65 Nūr-ı zāātı tọgı̀ıcak cin didi budur Ḥak Resūl

Zāhir itdi lafł̣ı vü ma nāsı Ḥaḳḳı dem-be-dem

40a 66 Kör ü șag̀ır oldılar ibşār ü inz̄ār idicek

Görüp işitdürmedi küffāra umy-ile șamem

4ob 67 Virmiş iken anlara kāhinleri oñdın haber

Kim bozllur dīniñüz ${ }^{13}$ irer bize renc ü elem

$41 \mathrm{a}$

68 Gökde yıldızlardan āteş atılup şeyțānlara

Yirde yüz üstine düşdi gördiler cümle șanem

M.'de “ Söyündi”
M.'de “ dinimüz" 
41b 69 Çün şühüb sürdi şeyāṭini țarīḳ-1 vahyden

Başlarına teng oldı cünd-i'14 İblīsüñ Harem

70 Kaçmada gūyā Yemen ebțālı idiler veya

Şol ḳavim kim bir avuç țoprag ile oldı 'adem

42b $\quad 71$ İtdi tesbīh eyleyüp iki mübārek keffine

Nite itdi Yūnusı ḥùt olmış iken mülteḳam

43a 72 Dåvetine geldi ag̉açlar oluban sācidāt

Yüriyü yüriyü sāḳı üzre anlar bī-ḳadem

43b 73 Döndi girü yirine yazardı yirde kökleri

Nitekim leṿ̣ üstüne kātib yazar çekse ḳalem

44a 74 Var idi buluṭ gibi her ḳande gitse sāyebān

Șaḳlar idi cismini tā irmeye günden elem

44b 75 İçerem and iki şaḳ olan ḳamerle kim anuñ

Kalbine var nisbeti kim oldı mebrūrü'l-ḳasem

76 Ġār-ı kūh-ı Ŝevr oldı cāmi -i ḩayr ü kerem

Oldı küffāruñ gözi kör anda olduḳları dem

45b $\quad 77$ Șıdḳ-ile Șıddīḳı ol gāār içre kimse görmedi

Didi kāfirler bu gāāa bașmamış kimse ḳadem

46a 78 Beyża ḳomadın gügercin urmadı tār 'ankebūt Șandı kāfirler o halḳuñ hayrı üstine ḳadem

46b 79 Ḥaḳ Te ālā șaḳladı a dāsı şerrinden anı Olmadı ḥācet-i zırh aña dahı ı̄ầ-uṭum

47a 80 Baña zulm itdükce gerdūn istedüm andan emān Ḳılmadı illā civār-ı Mușțafā def-i zulem

47b 81 İki ālemde yüzi șuyına her ne istedüm

Her murādımdan ziyāde buldum ị̣sān ü kerem

\footnotetext{
14 M.'de "cend"
} 
$48 \mathrm{a}$

82 Vahyi inkār eyleme düşünde kim ḳalbi anuñ

Uyanuḳdı uyḳusından nite uyanduğı dem

48b $\quad 83$ Evvel-i vahy-i nübüvvet oldı düşinde aña

Olmadı uyhususı ${ }^{15}$ münker nite h ${ }^{`}{ }^{2} \mathrm{~b}-1$ muḥtelim

49a 84 Ż̄-Te ālallāh degildür kesb ile vahyy-i rüsul

'̇lm-i ‘ayn ile nebī olmadı hergiz müttehem

49b $\quad 85$ Niçe kişiye şifā virdi mübārek ayası

Niçe Mecnūn ü lemem ehlini ol ḳurtardı hem

50a 86 Eyledi zā’il dưāsı ḳaḥt yılın ḩalḳdan

Oldı ḥattā ol sene çün gurre-i ḩayl-i dehem

5ob 87 Eyledügi dem du’ā yag̉dı yire bārān-ı hayr

Șanki vādīler baḥir oldı veyā seyl-i ‘Arim

$51 \mathrm{a}$

88 Ḥüsn-i dürrüñ muntaẓam olmag̀-ıla olur mezīd

Olmasa ger muntaẓam olmaya anuñ ḳadri kem

51b $\quad 89$ Ṭut ḳulaguñ mu cizātın diyeyin rūşen ola

Zulmet-i şebde nite āteş yana farḳ-ı 'alem

$52 a$

90 Her ne deñlü ${ }^{16}$ medḥ olunsa ḥaḳ medḥi olmaya

Andaki fażl ü ḥikem cūd ${ }^{17}$ ü kerem ḩulḳ ü şiyem

52b 91 Nāzil oldı Aḥmede āyāt-ı Ḥak raḥmāndan

Vaṣf-ı elfāẓı ḥudūṣ vașf-ı ma nāsı ḳıdem

$53 a$

92 Bir zamāna muḳterin olmadı virdi ol haber

Niçe olısar ma‘ād ü n’oldı `Ād ile İrem

53b 93 Kaldı bāḳ̄ yanımuzda mưcizātuñ yigregi

Bir nebīden mưcize olmadı böyle müstedem

M.'de "uykusı"

M.'de “deñ்ü” yok. VB.

M.'de "fażl ü kerem hikem ü cūd" 
54a 94 Oldı ahbārı muhakkem ḳalmadı șāḥib-şiḳāḳ

Şübhe īrādunda vü olmadı muḥtāc-ı ḥakem

54b 95 Ceng iden Ḳur'ān ile āḩir nedāmet eyledi

Ġāyet-ile düşmen olana bıraḳdurdı selem

55a 96 İtdi red Ḳur’ān belāgatle mu'āriż olanı

Red ider cānını șaḳlar nite gaayretlü ḥarem

55b 97 Mevc-i deryā gibi mánāsına yoḳ pāyān-ı ḥad

Dür-ile mercāndan artuḳ oldı ḥüsni her ḳıyem

56a 98 Şol ‘acāyib k’anda olunmaya ị̣ṣā vü 'aded

Her ne deñlü oḳusan tekrārını virmez se’em

56b 99 Gözi aydın ola oḳıyan kişinüñ ben ${ }^{18}$ didüm

Çün Ḥaḳuñ ḥablini bulduñ bek țut ol ehl-i ișām

100 Korḳuben nār-ı cehennemden oḳursañ ger anı

Eyleye nār-ı cehīmi anı vird itmek şebem ${ }^{19}$

$57 \mathrm{~b}$

101 Oḳıyanuñ yüzini aḳ eyler ol bir havżdur

Gerçi kim olsa yüzi ḳara 'uṣātuñ çün hịimem

58a 102 Ma`deletde oldı ol gūyā ki mīzān ü ṣırāt

Ṭog̉rı yol yoḳ halḳa andan g̉ayrı aṣlā bīş ü kem

58b 103 Ger ḥasūd inkār ide anı tecāhül eyleyüp

Sen 'aceb ḳılma anı ider ${ }^{20}$ hazāāḳat-le fehim

104 Kör olan kişi güneş aydınlıġın inkār ider

Nitekim ṣu lezzzetin inkār ider ṣāhịib-seḳam

59b 105 İşigi halḳa mețāf olanlaruñ sen yigregi

Sāî̄ vü rākib saña ḳılur teveccüh dem-be-dem

M.'de "ben” yok. VB.

M.'de "siyem"

M.'de "ider anı" 
60a 106 Ítibār ehli olana āyet-i kübrā özüñ

Nïmet-i uẓmā vücūduñ ḩalk-ı ālem muġtenem

6ob 107 Bir gice ḳılduñ Ḥaremden Mescid-i Aḳ̣āyl ${ }^{21}$ seyr

Nitekim seyr eyleye bedr olsa gice pür-ẓulem

61a 108 Menzilüñ oldı yüce dergāh-ı Haḳdan ol gice

Bir yire irdüñ ki² $^{22}$ anda bașmadı kimse ḳadem

61b 109 Enbiyā vü mürselīn ol gice taḳdīm itdiler

Sen Resūli nite taḳdīm ide maḩdūm-ı hadem

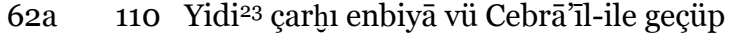

Anlaruñ içre sen idüñ ol gice ${ }^{24}$ șāhib-'alem

62b 111 Sidreden geçdüñ öte varduñ cenāb-ı Hażrete

Andan ilerü melā’ik efżalı bașmaz ḳadem

63a 112 Menzilüñe göre alçaḳ oldı her 'ālī-maḳām

Bir yire irdüñ ki yektā olduñ anda çün 'alem

63b 113 Görüp işidilmedigi menzile bulduñ vüșūl

Saña keşf oldı 'aṭā-yı sırr-ı bāb-ı müktetem

64a 114 Saña virilen sa ādet kimseye virilmedi

Lüț-ile ị̣sān ü fażlın Ḥaḳ saña ḳıldı etem²5

64b 115 Oldı miḳdāruñ yüce rütbeñ maḳāmuñ key bülend

Vașf olunmaz Haḳ saña virdügi ulu ni’am

65a 116 Z̄ī-sa'ādet ži-beşāret bizlere iy müslimīn

Ḳıldı Ḥaḳ bize ināyet rükn-i gayr-ı münhedim

65b 117 Enbiyānuñ ekremin Ḥaḳ bize gönderdi resūl

Ḳıldı anuñ yüzi șuyına bizi ḩayr-ı ümem

M.'de "Aksāya"

M.'de "irdüñ gice

M.'de "Yedi"

M.'de "gece"

$114 \mathrm{~b}$ ve $115 \mathrm{~b}$ Aşir Efendi nüshasında aynıdır. 
66a 118 Dillerin ḳorḳıtdı a'dānuñ șadā-yı bi șeti

Nāgehān āvāzeden şol resme kim ürker ganem

66b 119 Gönderilen ḳıldı a dāsı tenin her cengde

Nite ḳașṣāb olan aṣar laḥmı tọgradı̀̇ı dem

67a 120 Kaç̧ı cengden 'adūlar ġıbța eylerken aña

Oldılar a żāsı hem pervāz ukāāb u raham

67b 121 Şol gice kim ceng-ile anuñ hirāsından 'adū

Bilmedi ta dādını gaayr-ı şeb-i māh-ı ḥaram

68a 122 Oldı dīn sādāt ile gūyā ki mihmān-ı ’adū

Düşmeni ḳaçana 'atşān laḥmına olup ḳarem

$68 \mathrm{~b}$

123 'Askerī deryāsını çekdi süvār idüp ḳamu

Pehlevānlar ${ }^{26}$ içlerinde oldı mevc-i mültețım

69a 124 Şevket-i dīn-i rıżā-yı Ḥaḳ içün çalışdılar

Ḳılmaga küffārı müste’ṣıl ser-ā-ser muṣṭalem

69b 125 Millet-i İslām ü dīn-i Ḥaḳ garīb ü hōōken

Buldı ḳavm-i aḳrabā oldı mükerrem muḥterem

$70 \mathrm{a}$

126 Bir saēādetlü ata devletlü bir er buldı dīn

İrmeye tā ḥaşr olunca aña ālām-ı yetīm

70b 127 'Asker-i İslāmuñ oldı her biri gūyā ki kūh

Hașmına șor anlaruñ ne gördiler her mușțadım

$71 \mathrm{a}$

128 Ṣor Ḥuneyn-ile Uhưd Bedr ehlinüñ ahvālini

Niçe gördiler vebādan ḳatıraḳ mevt ü elem

71b 129 Ag-iken²7 sürh idi şimşīr-i guzātı hūun-ı küfr

Rūşen oldı şem e-i dīnn ${ }^{28}$ maḥv oldı küfr-i pür-ẓulem

M.'de "Pehlüvānlar"

M.'de "ak iken"

M.'de "dìn"yok VB. 
$72 a$

$72 b$

$73 \mathrm{a}$

$73 b$

$74 \mathrm{a}$

$74 \mathrm{~b}$

$75 \mathrm{~b}$

$76 \mathrm{a}$

$76 b$

$77 \mathrm{a}$

$77 \mathrm{~b}$

130 Ḥatț-ı sürḩi yazdılar oldı ḳalem seyf ü sinān

Kalmadı ${ }^{29}$ cism-i 'adūdan cism-i gayr-ı mün'acem

131 Pehlevānlıḳlarına3º sīmāları oldı nișān

Būy ü rengi birle mümtāz ola verd-ile selem

132 Vaḳt-i heycādan zuhūr eylerler anlar çün silāḥ

Evde olurlar gül ekmāmında gibi müktetem

133 Șan dırahțt-ı kūhdur her biri olduḳ da süvār

İremez birbirisinden ${ }^{31}$ peyk-i ādem bir ḳadem

134 Ditredi düşmenlerüñ göñli bulardan ḳorḳuban

İtmediler farḳın insān-ile hayvānuñda hem

135 Her kimüñ yardımcısı ola Resūlullāh eger

Ug̉rasa şīr üstüne şīr eyleye 'azm-i ecem

136 Bir șadīḳı yoḳ-durur olmaya nuṣret aña yār

Bir 'adūsı yoḳ-durur olmamış ola müntaḳım

137 Milleti ḥırzında ḳıldı ümmetin āsūde ḥāl

Yavruların niçe șaḳlar şīr idüp mesken ecem

138 Kim cedel ḳıldı kelām-ı Haḳ-ile düşdi yire

Oldı bürhān ile mülzem şol kişi ki oldı ḩaṣm

139 Mưcize yiter kemāl-i 'ilm ü fażl ümmī iken

Vahyden evvel yetīm iken mü'eddeb ola hem

140 Hֵıdmet itdüm aña bu medh-ile ümmīd eyleyüp

Zenb-i ömrüm ‘afv ola didüm şi ir itdüm ḩıdem

141 Ġayr-ı Ḥaḳka itdügüm ḩıdmet hevāda sözlerim

Oldı boynımda 'alāmet nitekim hedy ü ne’am 
$78 \mathrm{a}$

142 İki hâaletde ṣıbāğıyyete uydum ḥāṣılum

Olmadı illā ki zzenb ü ma’șıyet iṣm ü nedem

$78 \mathrm{~b}$

143 Key hasāret irdi nefse kim ticāret eyledi

Dīn-i dünyā-ile șatun almadı ol bī-nehem

$79 a$

144 'Ācil-i dünyāya her kim șatdı 'uḳbā ācilin

Ġabn-ı fāḥiş olur itdügi ḳamu bey’ ü selem

$79 \mathrm{~b}$

145 Her ne deñlü kim günāh itdümse 'ahdüm bozmadum

Ṭutmışam ḥabl-i Resūli muḥkem elden ḳomazam

80a 146 İsmüm anuñ ismi oldıġından ị̣sān umaram

Ol-durur erbāb-ı fażluñ serveri șāḥib-kerem

8ob 147 Dest-i fażlı rūz-ı mạ̣şerde elim țutmaz ise

Ben șırāṭ-ı müsțaḳimm üzre ayaḳ niçe bașam

81a 148 Mücrim ü muhtāca hâaşā kim şefāaat itmeye

Yā civārında olanlar ola gayr-ı muhterem

$81 \mathrm{~b}$

149 `Aḳl ü fikr ü țabımı medḥine meşḡūl eyledim

Umaram andan meded her kes meded umdugi dem

82a 150 Her ne deñlü kim faḳī olsañ ḳlur luṭf-ı ganī Bitürür rengīn çiçekler olıcak yaġmur ekem

82b 151 Ḳılmadum ol pādişāhuñ medḥini dünyā içün Nitekim ḳldı Züheyr anuñ içün medḥ-i Herem

83a 152 Melce’üm yoḳdur ḳapuñdan gayrı iy halk ekremi İki ‘ālemde țapuñdan umaram fażl ü kerem

83b 153 İntiḳāmı-y-la tecellī idicek Rabb-i kerīm Eyleseñ baña şefāat mertebeñ olmaya kem

84a 154 Bå̇̇̀ cūduñdan-durur dünyā-ile hem āḩiret Båżı ilmüñden-durur Levḥe ne yazdıysa Kalem 
84b 155 Kesme raḥmetden ümīd iy dil günāhuñ olsa çok

Mağfiret bahrında zenbī ālemüñ bir ḳațreyem

85a 156 Umaram taḳsīm-i rạ̣met ḳılıcaḳ Rabbüm ḳıla

Fażl ü ị̣sānını cürm ü zenbe göre münḳasım

85b 157 Eyleme yā Rab cenābuñda ricāmı mün'akis

Hem ‘nāyet ḳıl sühūletle ḥısābumı virem

86a 158 İki 'ālem içre ḳıl ben ḳuluña yā Rab lüṭuf

Yoḳ-durur ehvāle șabr ü țāḳatüm sen ḳıl kerem

86b 159 Raḥmet-i in'āmunuñ ebrine emr it dā’imā

Yaġdura bārān-ı ifżālüñ Resūle dem-be-dem

87a 160 Āline aṣḥābına etbāina dahı selām

Ehl-i 'ilm ü ḥilm ü taḳvā pāk-ilen ehl-i kerem

87b 161 Bōstān-ı dehrde mādem² ${ }^{2}$ ese bād-ı șabā

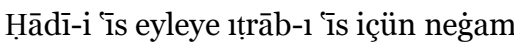

\section{Kaynakça}

Alan, Hüseyin (2014). Siyerin Gölgesinde Hz. Peygamber Öncesi Mekke ve Arabistan. İstanbul: Beyan. Armutçuoğlu, İlhan( 2009).Kaside-i Bürde. İstanbul:Erkam.

Cankurt, Hasan (2015). Seyyid Hasan Rzzâyî El-Aksarâyî Hayat,, Sanatı, Eserleri ve "Miftâhu'sSa'âde" adlı Manzum Kasîde-i Bürde Şerhi. Aksaray: Aksaray Valiliği İl Kültür ve Turizm Müdürlüğü Yay.

Çağatay, Neşet (1957). İslamdan Önce Arap Tarihi ve Cahiliye Çağı. Ankara: Ankara Üniversitesi İlahiyat Fakültesi.

Çavuşoğlu, Mehmed (1986). Türk Dili Türk Şïri Özel Sayısı II. Divan Şiiri-Kaside. İstanbul: Türk Dil Kurumu.

Çelebi, Ahmet (1997). İslam Öncesi Mekke ve Tarih Anlayışımız. Çev.H.Fehmi Ulus.İstanbul: Seriyye Kitapları.

Eliaçık, Muhittin (2009). “Şemsi Paşa'nın Manzum ve Muhtasar Vikâyetü’r-Rivâye Tercümesi”. Şarkiyat İlmi Araştırmalar Dergisi 2: s. 16-49.

Eğri, Sadettin (2013). “Edebiyatta Bedîiyyeler ve Bir Kaside-i Masnûa İncelemesi”.Bilig. Türk Dünyası Sosyal Bilimler Dergisi 65: s. 151-164.

Ergun, Sadeddin Nüzhet ( 1936).Türk Şairleri. C. 3.İstanbul: 1341.

Furat, Ahmet Suphi ( 1996). Arap Edebiyatı Tarihi. İstanbul: İstanbul Üniversitesi Edebiyat Fakültesi.

Güleç, İsmail (2013).“Kaside-i Masnû́a İle Bedîiyye Aynı Şey midir?”İstanbul Üniversitesi Edebiyat Fakültesi Türk Dili ve Edebiyatı Dergisi XLVIII: s. 63-70.

\footnotetext{
$32 \quad$ M.'de "mādām"
} 
Izutsu, Toshihiko (2013). Kur'an'da Dinî ve Ahlâkî Kavramlar. Çev. Selahattin Ayaz.İstanbul: Pınar.

Hilmi, Ö. Faruk (2013). Kelime Manah Kaside-i Bürde Şerhi, Fazileti, Havas ve Esrârı. İstanbul Tuğra Neşriyat.

Kademoğlu, Mahmut (2000). Kaside-i Bürde. Şâmil İslam Ansiklopedisi. C.4.İstanbul: Şâmil Yay.

Kahraman, Bahattin (1991). "Bûsırî'nin Kasîde-i Bürde'si Etrafında Yazılmış Türkçe Eserler".S.Ü. FenEdebiyat Fak. Edebiyat Dergisi S.6, s.167-174.

Kahraman, Bahattin (1997). "Le'âli ve Abdurrahîm Karahisârî̀nin Manzum Kasîde-i Bürde Tercümeleri”.Türkiyat Araştırmaları Dergisi S.4, s.57-107.

Kaya, Mahmut ( 2011). Kaside-i Bürde'yi Türkçe Söyleyiş. İstanbul: Damla Yayınevi.

Kaya, Mahmut (1998).“İmam Busîrî ve Kasîde-i Bürde”. Altınoluk Dergisi, S.154, s.38.

Kuzubaş, Muhammet (2007).“Muhammed Fevzînnin Miftâhu'n-Necât Adlı Eseri” (Kasîde-i Bürde Tahmis ve Şerhi). Uluslararası Sosyal Araştırmalar Dergisi 1/1, s.156-192.

Sak, Vesile Albayrak (2013).“Said Paşa'nın Kaside-i Bürde Tahmisi”.Turkush Studies-İnternational Periodical For The Language, Literature and History of Turkush or Turkac 8/9, s. 523-559.

Sak, Vesile Albayrak (2014)."Şemseddin Sivâsî’nin Kaside-i Bürde Tercümesi”. Turkısh StudiesInternational Periodical For The Language, Literature and History of Turkısh or Turkı 9/3, S.91-110.

Saraç, M. A.Yekta (2004). "Salahaddin-i Ușşakî”nin Belâgat İle İlgili Eseri ve Bu Eserdeki Edebî Terimler”. İstanbul Üniversitesi Edebiyat Fakültesi Türk Dili ve Edebiyatı Dergisi XXXI, s.281318.

Saraç, M. A.Yekta (1995). Şeyhülislam Kemal Paşazâde: Hayatı, Şahsiyeti, Eserleri ve Şïrleri. İstanbul: Risale Yay.

Sezer, İ.Hakkı (2000).“Kaside-i Bürde ve Nesir ve Manzum Tercümesi”. Selçuk Üniversitesi İlahiyat Fakültesi Dergisi, S.1, s.65-88.

Şahin, E. Sıddık (1997). Kaside-i Bürde’nin Türkçe Şerh ve Tercümeleri. Yüksek Lisans Tezi. Ankara: Gazi Üniversitesi.

Türk Dili ve Edebiyatı Ansiklopedisi (1977). Devirler-İsimler-Eserler-Terimler. C.5. İstanbul: Dergâh Yay. 212-214.

Yeniterzi, Emine (2010). "Bir Edebi Tür Olarak Natlar".Uluslararası Mevlid Sempozyumu. Ankara:Türkiye Diyanet Vakfı Yay. 